\title{
Chemical Composition and Antimicrobial Activity of Extracts from Thyme and Rosemary Against Staphylococcus aureus and Candida albicans
}

\author{
Akram Sabzikar, ${ }^{a}$ Seyyed Khalil Hosseinihashemi, ${ }^{\text {b* }}$ Younes Shirmohammadli, ${ }^{\mathrm{c}}$ and \\ Abbas Jalaligoldeh ${ }^{\text {a }}$
}

\begin{abstract}
Different concentrations of ethanolic extracts of thyme (Zataria multiflora) and rosemary (Rosmarinus officinalis) were evaluated to determine their antimicrobial activity using the agar-well diffusion method. The values of inhibition zone diameter (IZD) for Candida albicans fungus and Staphylococcus aureus Gram-positive bacteria were determined. The bioactivities of two various extracts were studied, and the chemical composition of the extracts were identified using gas chromatographymass spectrometry (GC-MS) technique. The results of the test showed that at concentrations of $10 \%$ and $40 \%$ thyme extract, the values of IZD were $12.5 \mathrm{~mm}$ and $23.3 \mathrm{~mm}$, respectively, against the growth of $S$. aureus, which were higher than $C$. albicans $(7.0 \mathrm{~mm}$ and $22.5 \mathrm{~mm}$, respectively). The rosemary extract at concentrations of $20 \%$ and $60 \%$ showed lower antibacterial activity against $S$. aureus $(4.7 \mathrm{~mm}$ and $8.7 \mathrm{~mm}$ IZD, respectively) and lower antifungal activity against $C$. albicans $(12.2 \mathrm{~mm}$ and $1.7 \mathrm{~mm}$ IZD, respectively). At a concentration of $40 \%$ thyme extract, the highest antibacterial (23.3 $\mathrm{mm}$ IZD) and antifungal (22.5 mm IZD) activities were observed. The GC/MS analysis showed that carvacrol (52.3\%), linalool $L(16 \%)$, and thymol (9.6\%) were the main components of thyme extract, while in the rosemary extract $\beta$-amyrone $(18.0 \%)$, verbenone $(8.0 \%)$, and 1,8 -cineole $(7.26 \%)$ were the major constituents.
\end{abstract}

Keywords: Thyme and rosemary extracts; Antimicrobial activities; GC-MS; Carvacrol; $\beta$-amyrone

Contact information: a: Department of Horticulture, Karaj Branch, Islamic Azad University, Karaj, Iran; b: Department of Wood Science and Paper Technology, Karaj Branch, Islamic Azad University, Karaj, Iran; c: Department of Civil and Environmental Engineering, Faculty of Engineering, The University of Auckland, Auckland, New Zealand; *Corresponding author: hashemi@ kiau.ac.ir

\section{INTRODUCTION}

In recent years, due to worldwide antibiotic resistance, the tendency of using herbal medicine has increased and application of extracts instead of chemical preservatives in controlling microorganisms has received significant interest and attention (Bidaki et al. 2015; Raeisi et al. 2019).

The rosemary (Rosmarinus officinalis, family Lamiaceae) is a small evergreen shrub, growing approximately to 1 to $2 \mathrm{~m}$ tall and exists all over the world with slender, long, sharp, and slightly rough leaves along with purple-white flowers (Mirheydar 2001; Atti-Santos et al. 2005). Various parts of this plant, including the stems, branches, flowers, and leaves, have been used extensively for pharmaceutical products and traditional medicinal purposes (Mirheydar 2001; Tavassoli et al. 2011; Azizkhani and Tooryan 2015). Furthermore, rosemary is extensively used as a food additive and preservative (Frankel et al. 1996a). 
Zataria multiflora Boiss. (thyme) is a perennial plant of the Lamiaceae family, which is mainly grown in Iran, Pakistan, and Afghanistan (Ali et al. 2000). It is a medicinal plant used in traditional folk remedies due to positive effects for human health, such as its carminative, antiseptic, and analgesic properties (Shafiee and Javidnia 1997). Recent studies have revealed that thyme has antibacterial, antifungal, and antioxidant properties (Ramezani et al. 2004; Shokri et al. 2006; Babaie et al. 2007).

The traditional uses of thyme are as an antiseptic, vermifuge, anesthetic, antispasmodic, anthelmintic, antidiarrheal, and analgesic, but its current uses of pharmaceutical forms include treatment of irritable bowel syndrome, stomachache, flatulence, cough, bronchitis, laryngitis, candidiasis, and trichomoniasis (Sajed et al. 2013).

For example, the dry parts of the plant are used as flavor additive and preservative in a variety of foodstuffs in Iran (Gandomi et al. 2009). It has inhibitory effects against radial fungal growth and aflatoxin production by Aspergillus flavus in cheese (Gandomi et al. 2009). The extracts and essential oil of thyme prevent the growth of some bacteria associated with gastrointestinal infections from Staphylococcus aureus (Fazlara et al. 2008), enterohemorrhagic Escherichia coli (Goudarzi et al. 2006), Salmonella Typhi and Paratyphi (Fazeli et al. 2007), and Shigella flexneri and Bacillus cereus (Fazeli et al. 2007; Misaghi and Akhondzadeh Basti 2007).

Unfortunately, the resistance of the bacteria to antibiotics has increased in recent decades. Previous studies reported that the dry leaves of thyme of Shiraz are used in food products as a retentive and to add flavour (Gandomi et al. 2009), which inhibits the progress of some microorganisms like bacteria and fungi (Shafiee and Javidnia 1997). The thyme of Shiraz is a potential alternative to antibiotics against bacteria. It has antioxidant and antimicrobial essences having monoterpenes combinations (Saei-Dehkordi et al. 2010). Previous research reported that thyme has phenolic components such as thymol, carvacrol, linalool, and parasmyn. Thymol is one of the important compounds of the oxidized monoterpene and is antibacterial, antifungal, and avoids mycotoxins production, which is found in the essence of thyme and many other herbs (Tiwari et al. 2009). Interest in natural flavours in the food packing industry has increased in the last two decades due to their significant advantages, such as being a sustainable and environmentally friendly raw material, and being non-toxic for humans as compared to the chemical antimicrobial and synthetic substances (Yanishlieva et al. 1999). Using natural flavours as antibacterial combinations is a good solution to control pathogenic bacteria, increase the durability of processed foods, and reduce economical losses resulting from food-deteriorating microorganisms (Ali et al. 2000). In general, the increase in the phenolic contents positively affects the antibacterial resistance to the nutritional pathogens.

Candida albicans belongs to the Candida species and is one of common pathogens in patients with organ transplantation, acquired immune deficiency syndrome (AIDS), neoplastic disease, immunocompromised patients, users of immunosuppressive drugs, and broad-spectrum antibiotics (Bineshian et al. 2018).

One of the widespread pathogens that can cause a wide spectrum of infections, from superficial skin infections to severe and potentially fatal invasive disease, is Staphylococcus aureus (Lowy 1998). The S. aureus can rapidly grow in foods and is known as the most common foodborne microorganism (Kadariya et al. 2014).

Currently, there have been no reports on the chemical composition and antimicrobial properties comparison of the aerial parts of the thyme (Shirazi thyme) and rosemary extracts. Therefore, the present study aimed to evaluate and compare the 
chemical composition, antibacterial, and antifungal properties of extracts of Z. multiflora and R. officinalis.

\section{EXPERIMENTAL}

\section{Plant Materials}

The leaves and branches of Z. multiflora and R. officinalis plants were obtained from the Taleghan province, Qazvin, Iran and Nazarabad province, Karaj, Iran, respectively. Identification of the plants was carried out in the Department of Horticulture, Faculty of Agriculture and Natural Resources at Islamic Azad University, Karaj Branch, Iran.

\section{Removal of Extracts}

The plant parts of rosemary and thyme, including leaves and branches, were separately cut into small pieces, and chopped to obtain lignocellulosic flour. The particle size was between 30- and 40-mesh. In the first step, a little cotton was compressed and placed at the bottom of the $250 \mathrm{~mL}$ separatory funnel at the beginning of the outlet valve. In the second step, approximately $50 \mathrm{~g}$ powder of each tested plant material was poured into a separatory funnel, followed by the addition of $150 \mathrm{~mL}$ of ethanol $(96 \%)$. The mixture macerated in the closed separatory funnel for $48 \mathrm{~h}$. The outlet of the separatory funnel was opened, and the liquid allowed drip slowly as specified in modified method by Rathi et al. (2006). The liquid was clarified by filtration and finally concentrated to dryness, in a rotary evaporator at a low temperature $\left(35\right.$ to $40{ }^{\circ} \mathrm{C}$ ) to avoid chemical alteration in the bioactive compounds with loss of their properties. The extracts were accumulated and dried over anhydrous sodium sulfate and then stored at $4{ }^{\circ} \mathrm{C}$ (Hashemi et al. 2013).

\section{Culture Media and Inoculum}

The strains of $S$. aureus and $C$. albicans were sourced from the Iran's fungus and bacteria center and then transferred on tryptic soy broth (TSB). The applied TSB contained $17 \mathrm{~g} / \mathrm{L}$ tryptone (pancreatic digest of casein), $3 \mathrm{~g} / \mathrm{L}$ peptone (soybean digest), $2.5 \mathrm{~g} / \mathrm{L}$ glucose, $5 \mathrm{~g} / \mathrm{L} \mathrm{NaCl}$, and $2.5 \mathrm{~g} / \mathrm{L} \mathrm{K}_{2} \mathrm{HPO}_{4}$. To regenerate the $S$. aureus, the culture media was placed in an oven at $37^{\circ} \mathrm{C}$ for $48 \mathrm{~h}$ and to regenerate the C. albicans, the culture media was placed in an incubator at $25^{\circ} \mathrm{C}$ for $24 \mathrm{~h}$.

According to the culture media datasheet, $65 \mathrm{~g}$ powder of Sabouraud dextrose agar (SDA) for the fungus cultivation media and $34 \mathrm{~g}$ powder of Müller-Hinton agar (MHA) for bacteria cultivation media was added to $1000 \mathrm{~mL}$ of distilled water, separately, and placed on a heater with stirrer until a uniform solution was obtained. Next, the solution was sterilized in an autoclave at $121^{\circ} \mathrm{C}$ and $1.2 \mathrm{~atm}$ for $20 \mathrm{~min}$. Approximately $25 \mathrm{~mL}$ of the prepared culture media was poured into each sterile Petri plates.

\section{Antifungal and Antibacterial Activity Assessment}

Agar-well diffusion is one of several bioassessment methods that is well known and commonly used (Balouiri et al. 2016). Therefore, agar-well diffusion method was applied to determine the zone diameter of inhibition. The MHA $(34 \mathrm{~g} / \mathrm{L})$ for the cultivation of $S$. aureus Gram-positive bacteria and SDA $(65 \mathrm{~g} / \mathrm{L})$ for the cultivation of $C$. albicans fungus were used. Approximately $25 \mathrm{~mL}$ of molten media cooled to $45{ }^{\circ} \mathrm{C}$ was added to pre-sterilized Petri plates. After that, 48-h-old cultures of $S$. aureus, 24-h-old cultures of $C$. 
albicans were spread using a sterile cotton swab and loop, and each microbe was evenly spread over the entire surface of the agar dish to obtain a uniform dish surface growth. Next, the Petri plate (s) contents were cooled and dried. Three wells with 6-mm diameter and 5-mm depth were punched into the agar using a sterile glass Pasteur pipette for placing the extracted samples and dimethyl sulfoxide (DMSO) as the control sample. The extract solution was passed by syringe from a $0.45-\mu \mathrm{m}$ Microsolve filter and poured into a glass vial.

Approximately $0.05 \mathrm{~mL}$ (one drop) of the diluted extracts of each plant was dispensed into respective wells by syringe at various concentrations $(20 \%, 30 \%, 40 \%$, $50 \%$, and $60 \%$ for rosemary and $10 \%, 20 \%, 30 \%$, and $40 \%$ for thyme extracts on two wells and three Petri plates as replicates). The Petri plates were then left at room temperature for 30 min and then incubated at $30^{\circ} \mathrm{C}$ for 7 days. After incubation, the diameter of inhibition zones was measured using a ruler and the results were reported in millimeters (mm). All the tests were run in triplicate, and the average result was calculated (Sadeghi-Nejad et al. 2010; Bachheti et al. 2011).

\section{Analysis of Extracts}

The gas chromatography-mass spectrometry (GC/MS) analysis of the Z. multiflora and $R$. officinalis extracts was performed. Next, $1 \mu \mathrm{L}$ of each extract was dissolved with $100 \mu \mathrm{L}$ of ethanol, separately and run on a GC Agilent 7890A and MS Agilent 5975C mass spectrometer detector (Agilent Technologies, Palo Alto, CA, USA) equipped with a HP5MS cross-linked capillary column (30 m long and $0.25 \mathrm{~mm}$ internal diameter, $0.25 \mu \mathrm{m}$ film thickness). Helium was used as the carrier gas with a flow rate of $1 \mathrm{~mL} / \mathrm{min}$.

The GC/MS operation conditions were: injector temperature $260{ }^{\circ} \mathrm{C}$; transfer line $270{ }^{\circ} \mathrm{C}$; oven temperature program $60{ }^{\circ} \mathrm{C}$ for $4 \mathrm{~min}, 3{ }^{\circ} \mathrm{C} / \mathrm{min}$ to $100{ }^{\circ} \mathrm{C}$ for $2 \mathrm{~min}$, then 4 ${ }^{\circ} \mathrm{C} / \mathrm{min}$ to $250{ }^{\circ} \mathrm{C}$ for $5 \mathrm{~min}$; carrier gas was He at $1 \mathrm{~mL} / \mathrm{min}$. The intrinsic energy that hits the sample in the MS system was $70 \mathrm{eV}$. The split ratio of the sample was 50:1 with a split flow of $1 \mathrm{~mL} / \mathrm{min}$. Individual components were identified using mass spectra with data from literature, two mass spectrometric libraries (Wiley 275 L, 1998 and NIST-05), mass database matching, and by comparing the retention times and mass spectra of constituents with published data (Joulain and König 1988; Adams 1995, 2001). Retention indices $\left(R_{\mathrm{I}}\right)$ were determined with reference to a homologous series of normal alkanes ( $\mathrm{C}_{10}$ to $\left.\mathrm{C}_{32}\right)$ using Eq. (1) (Kováts 1958),

$$
R_{\mathrm{I}}=100\left[\left(n+(N-n) \times \log t_{\mathrm{RR}}(\mathrm{x})-\log t_{1 \mathrm{R}}\left(C_{\mathrm{n}}\right) / \log t_{\mathrm{IR}}\left(C_{\mathrm{N}}\right)-\log t_{1 \mathrm{R}}\left(C_{\mathrm{n}}\right)\right]\right.
$$

where $R_{\mathrm{I}}$ is the retention index of the compound of interest, $t_{1 \mathrm{R}}(\mathrm{min})$ is the net retention time $\left(t_{\mathrm{R}}-t_{0}\right), t_{0}(\mathrm{~min})$ is the retention time of the solvent (dead time), $t_{\mathrm{R}}(\mathrm{min})$ is the retention time of the compound of interest, $C_{\mathrm{n}}$ and $C_{\mathrm{N}}$ are the number of carbons in the n-alkanes eluting immediately before and after the compound of interest, respectively, and $N$ and $n$ are the numbers of carbon atoms in the $\mathrm{n}$-alkanes eluting immediately before and after the compound of interest, respectively.

\section{Statistical Analysis}

The results are given in mean values with their standard deviations. Statistical analysis was carried out using the SPSS program, version 22 (International Business Machines (IBM) Corp., Armonk, NY, USA). One-way analysis of variance (ANOVA) was conducted to determine the significance of differences between analytical results at $\mathrm{p}<$ 0.05 significance level. 


\section{RESULTS AND DISCUSSION}

\section{Antibacterial Activity}

Inhibition zone diameter (IZD) determination

Statistically, there were significant differences among the microbes (S. aureus and C. albicans), extracts (thyme and rosemary), and their concentrations (Tables 1,2, and 3). The effect of Z. multiflora ethanolic extract against $S$. aureus and C. albicans is provided in Fig. 1. The Z. multiflora ethanolic extract showed higher inhibition effect against $S$. aureus than $C$. albicans.

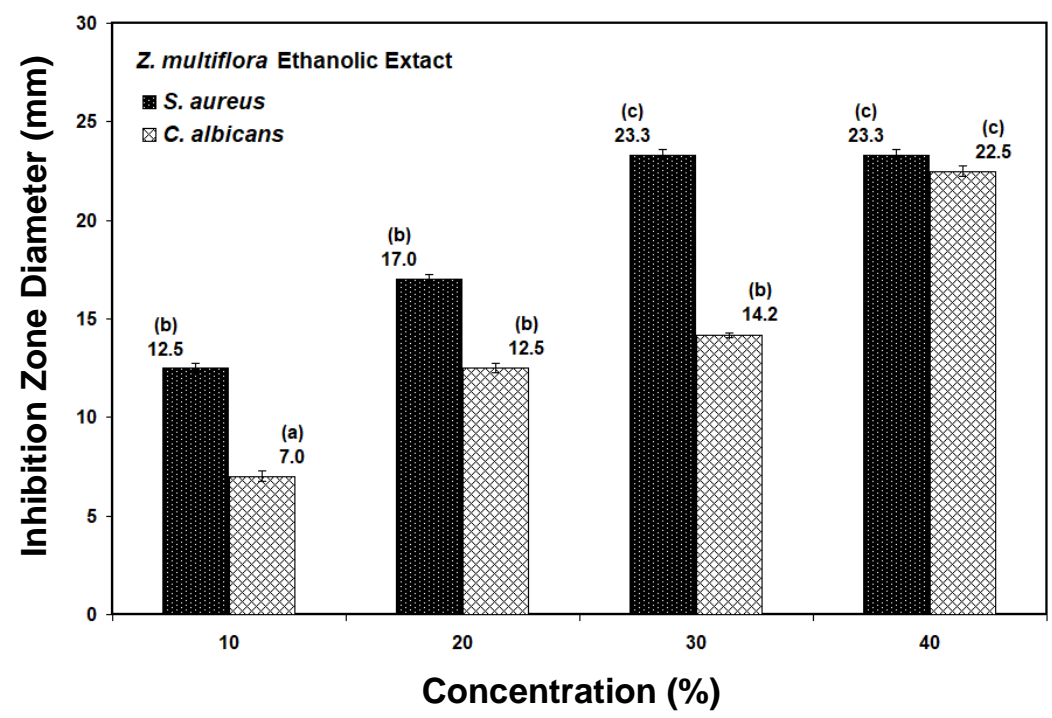

Fig. 1. Mean values \pm standard deviation of the IZD of the effect of $Z$. multiflora ethanolic extract against $S$. aureus and $C$. albicans at different concentration levels. Different letters in each column indicate a statistical difference $(p<0.05)$ among the treatment groups.

There was a significant difference between Z. multiflora ethanolic extract against S. aureus and C. albicans at concentrations of $10 \%$ and $30 \%$ and at $\mathrm{p}<0.05$ significance level (Fig. 1 and Table 1).

Table 1. Statistical Analysis of the Effect of Thyme Ethanolic Extract and Its Concentrations (Four Concentrations) on the IZD of S. aureus and C. albicans

\begin{tabular}{|c|c|c|c|c|c|}
\hline Source & Sum of Squares & df & Mean Square & F & Sig. \\
\hline Between groups & 7.720 & 7 & 1.103 & 17.131 & 0.000 \\
\hline Within groups & 1.030 & 16 & 0.064 & - & - \\
\hline Total & 8.750 & 23 & - & - & - \\
\hline
\end{tabular}

In general, with the increasing of extract concentration from 10 to $40 \%$, the inhibition effect of extract against two microbial pathogens increased. The highest IZD values obtained from the thyme extract were $23.3 \mathrm{~mm}$ and $22.5 \mathrm{~mm}$ for $S$. aureus and $C$. albicans, respectively. The lowest IZD values obtained from the thyme extract were 12.5 $\mathrm{mm}$ and $7 \mathrm{~mm}$ for $S$. aureus and C. albicans, respectively (Fig. 1).

Comparing the effect of rosemary extract on bacteria at the statistical level of 5\%, the change in the IZD up to 50\% concentration range was not significant but at a concentration of $60 \%$ was significant, which was determined as the optimum concentration (Table 2 and Fig. 2). 
Table 2. Statistical Analysis of the Effect of Rosemary Ethanolic Extract and Its Concentrations (Five Concentrations) on the IZD of S. aureus and C. albicans

\begin{tabular}{|c|c|c|c|c|c|}
\hline Source & Sum of Squares & df & Mean Square & F & Sig. \\
\hline Between groups & 2.867 & 9 & 0.319 & 17.949 & 0.000 \\
\hline Within groups & 0.355 & 20 & 0.018 & - & - \\
\hline Total & 3.222 & 29 & - & - & - \\
\hline
\end{tabular}

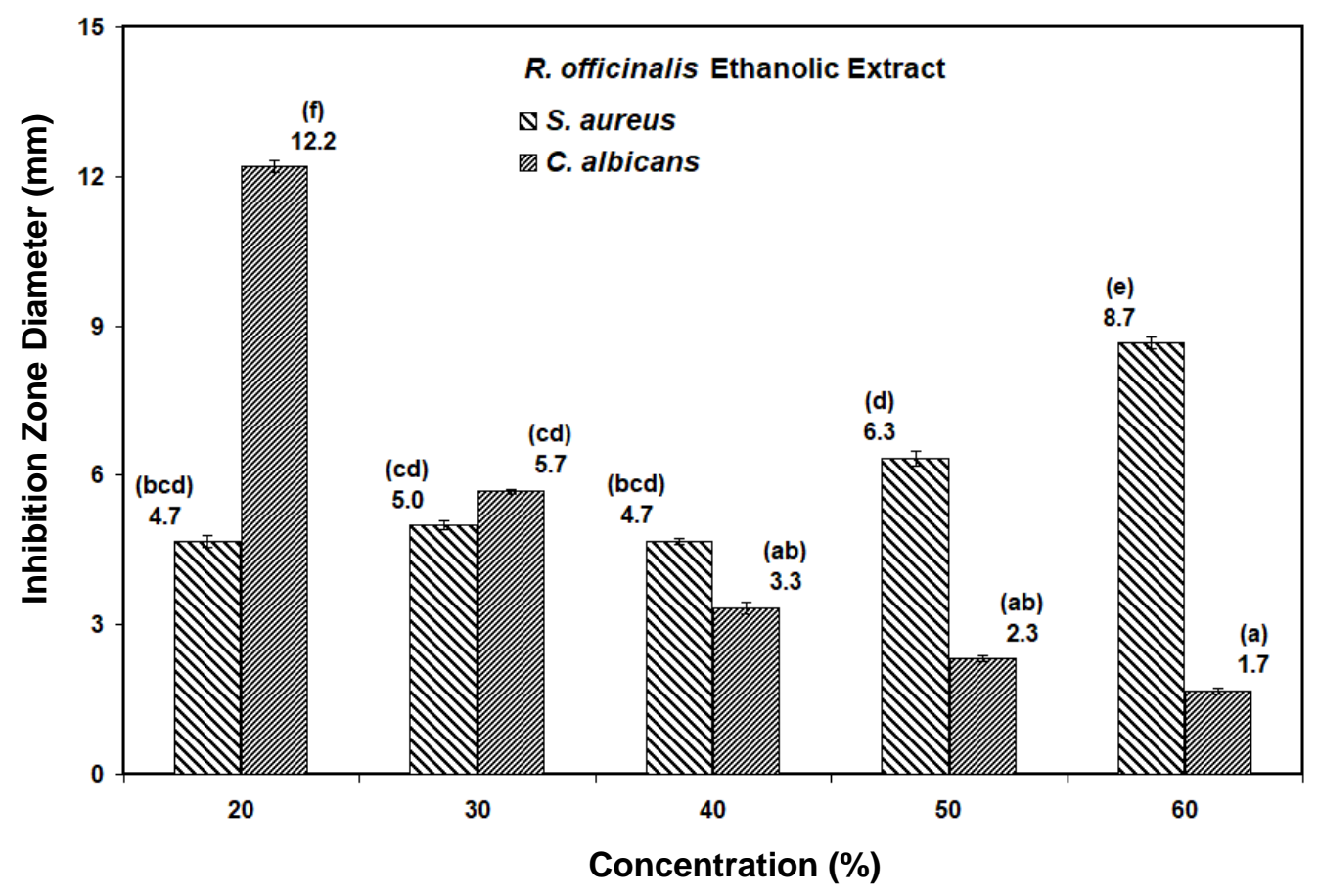

Fig. 2. Mean values \pm standard deviation of the IZD of the effect of $R$. officinalis ethanolic extract against $S$. aureus and $C$. albicans at different concentration levels. Different letters in each column indicate a statistical difference $(p<0.05)$ among the treatment groups.

With the increasing of rosemary extract concentration levels from 20 to $60 \%$, the inhibition effect showed a significant reduction against C. albicans (Swari et al. 2020), while with the increasing of rosemary extract concentration levels from 20 to $60 \%$, the inhibition effect showed an increasing trend against $S$. aureus (Fig. 2). The highest IZD values obtained from the rosemary extract were $12.2 \mathrm{~mm}$ and $8.7 \mathrm{~mm}$ for $S$. aureus and $C$. albicans, respectively. The lowest IZD values obtained from the rosemary extract were 1.7 $\mathrm{mm}$ and $4.7 \mathrm{~mm}$ for $S$. aureus and C. albicans, respectively (Fig. 2). According to the studies, the authors found that the type and content of some compounds can affect the antifungal and antibacterial activities of extracts at different concentrations (Matsuzaki et al. 2013; Abdulaziz et al. 2015). Based on the comparison of the IZD mean values, a significant difference was observed between the effects of rosemary and thyme extracts on the bacteria. The antibacterial effect of thyme extract was optimized more than the rosemary extract. Statistically, there was a significant difference between the extracts and their concentrations on the value of growth inhibition of microbes, bacteria, and fungus (Table 3 and Fig. 3). 
Table 3. Univariate Test Results of the Effect of Thyme and Rosemary Ethanolic Extracts and Their Concentrations (Three Concentrations, 20\%, 30\%, and 40\%) on the IZD of $S$. aureus and $C$. albicans

\begin{tabular}{|c|c|c|c|c|c|}
\hline Source & $\begin{array}{c}\text { Type III } \\
\text { Sum of Squares }\end{array}$ & Df & $\begin{array}{c}\text { Mean } \\
\text { Square }\end{array}$ & F & Sig. \\
\hline Corrected model & 20.024 & 11 & 1.820 & 42.280 & 0.000 \\
\hline Intercept & 55.502 & 1 & 55.502 & 1289.090 & 0.000 \\
\hline Microbes & 0.122 & 1 & 0.122 & 2.845 & 0.105 \\
\hline Extracts & 14.694 & 1 & 14.694 & 341.290 & 0.000 \\
\hline $\begin{array}{c}\text { Concentrations (Conc.) } \\
\text { Microbes } \times \text { Extracts } \times \\
\text { Conc. }\end{array}$ & 0.200 & 2 & 0.100 & 2.327 & 0.119 \\
\hline Microbes $\times$ Conc. & 1.210 & 1 & 1.210 & 28.103 & 0.000 \\
\hline Extracts $\times$ Conc. & 0.555 & 2 & 0.278 & 6.450 & 0.006 \\
\hline $\begin{array}{c}\text { Microbes } \times \text { Extracts } \times \\
\text { Conc. }\end{array}$ & 2.521 & 2 & 1.260 & 29.276 & 0.000 \\
\hline Error & 0.720 & 2 & 0.360 & 8.366 & 0.002 \\
\hline Total & 1.033 & 24 & 0.043 & - & - \\
\hline Corrected Total & 76.560 & 36 & - & - & - \\
\hline
\end{tabular}

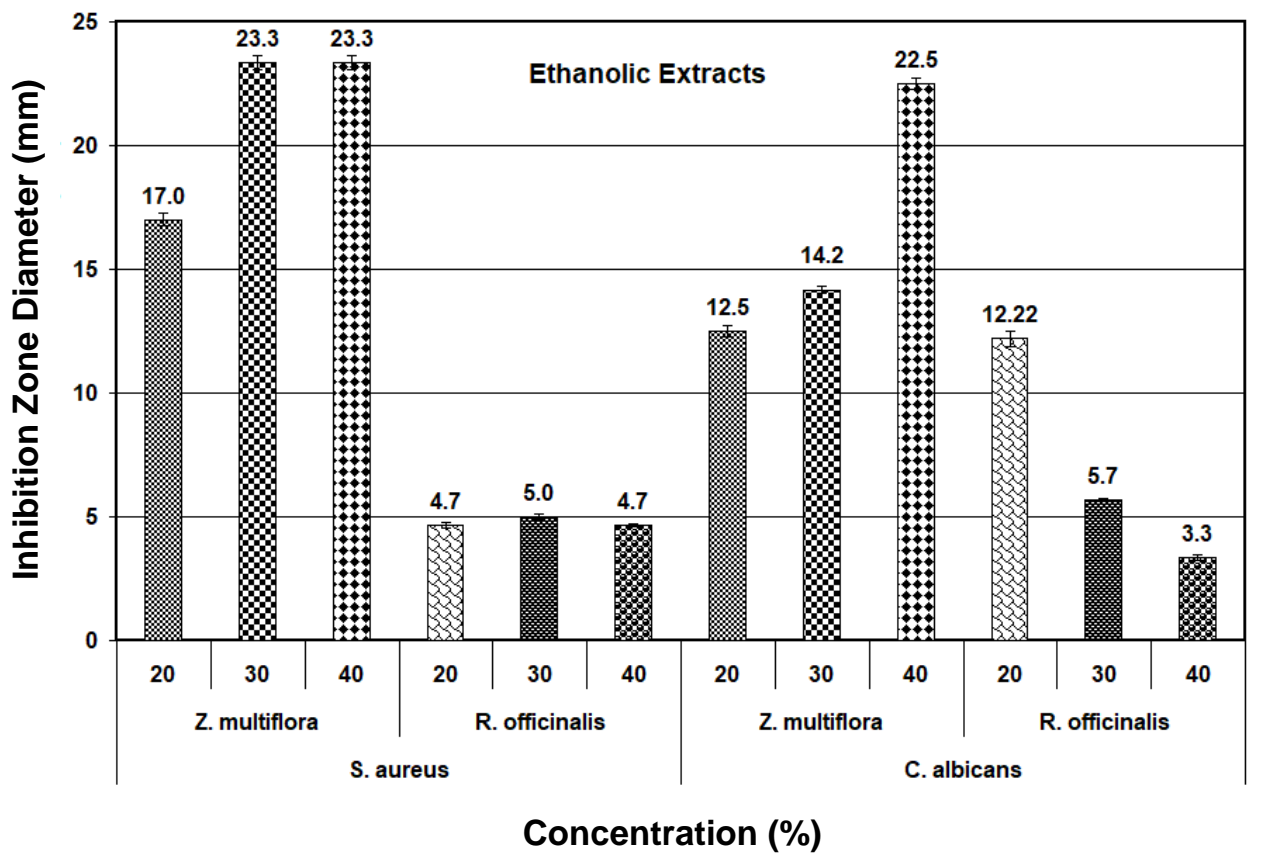

Fig. 3. Mean values \pm standard deviation of the IZD of the effect of thyme and rosemary ethanolic extracts at similar concentrations against $S$. aureus and $C$. albicans

Figure 3 illustrates that at similar concentrations the highest inhibition effect on the growth of bacteria, S. aureus showed at $30 \%$ and $40 \%$ concentration levels by Z. multiflora extract, while the highest inhibition effect on the growth of fungus, $C$. albicans showed at a concentration of $40 \%$. The antibacterial activity was classified according to Mutai et al. (2009): very strong response, zone diameter $\geq 30 \mathrm{~mm}$; strong response, zone diameter 21 to $29 \mathrm{~mm}$; moderate response, zone diameter 16 to $20 \mathrm{~mm}$; weak response, zone diameter 11 to $15 \mathrm{~mm}$; and little or no response, zone diameter $\leq 10 \mathrm{~mm}$. According to the 
classification of IZD, the thyme extract is placed in two classes of moderate (zone diameter 16 to $20 \mathrm{~mm}$ ) to strong (zone diameter 21 to $29 \mathrm{~mm}$ ), but the rosemary extract is placed in two classes of little or no response (zone diameter $\leq 10 \mathrm{~mm}$ ) to weak (zone diameter 11 to $15 \mathrm{~mm}$ ) (Mutai et al. 2009).

\section{Extracts Analysis}

Chemical composition of thyme extract

To further investigate the chemical constituents in these plants, in this study, a total of 24 and 32 compounds were separated, and they were identified in the thyme and rosemary extracts, respectively (Tables 4 and 5). The main constituents of the extracts of the tested two plants identified by GC/MS are presented in Tables 4 and 5 according to their percentage composition.

Table 4. Characterized Chemical Composition of Ethanolic Extract of $Z$. multiflora

\begin{tabular}{|c|c|c|c|c|}
\hline No. & Compound & $\begin{array}{c}\mathbf{R T}^{*} \\
(\mathbf{m i n})\end{array}$ & $\begin{array}{c}\text { Relative Area } \\
\text { Percent (\%) }\end{array}$ & $\mathbf{K I}^{* *}$ \\
\hline 1 & Benzene, 1-methyl-4-(1-methylethyl)- & 6.995 & 1.09 & 1030 \\
\hline 2 & 1,8-Cineole & 7.120 & 0.52 & 1037 \\
\hline 3 & gamma-Terpinene & 7.711 & 0.54 & 1065 \\
\hline 4 & Linalool oxide cis & 7.996 & 0.52 & 1078 \\
\hline 5 & Linalool oxide (2) & 8.328 & 0.55 & 1092 \\
\hline 6 & Linalool L & 8.603 & 15.96 & 1104 \\
\hline 7 & 3,7-Octadiene-2,6-diol, 2,6-dimethyl- & 10.554 & 1.96 & 1198 \\
\hline 8 & Carvacrol methyl ether & 11.561 & 0.53 & 1250 \\
\hline 9 & Linalyl acetate & 11.753 & 1.16 & 1260 \\
\hline 10 & Thymol & 12.614 & 9.59 & 1301 \\
\hline 11 & Carvacrol & 12.863 & 52.32 & 1315 \\
\hline 12 & 1-Methylpyrroline & 13.252 & 3.53 & 1336 \\
\hline 13 & Carvacryl acetate & 14.067 & 0.56 & 1379 \\
\hline 14 & Trans-caryophyllene & 15.011 & 3.43 & 1430 \\
\hline 15 & Aromadendrene & 15.364 & 0.40 & 1450 \\
\hline 16 & (+) Spathulenol & 17.808 & 0.63 & 1590 \\
\hline 17 & Caryophyllene oxide & 17.896 & 1.32 & 1595 \\
\hline 18 & $1 \mathrm{H}$-Cyclooctapyrazole, 4,5,6,7,8,9-hexahydro- & 23.121 & 0.61 & 1939 \\
\hline 19 & $2-P e n t a d e c a n o n e$ & 24.066 & 0.98 & 2007 \\
\hline 20 & Phytol & 25.539 & 0.34 & 2117 \\
\hline 21 & Di-(2-ethylhexyl)phthalate & 30.707 & 0.63 & 2554 \\
\hline 22 & Squalene & 33.613 & 0.63 & 2833 \\
\hline 23 & Vitamin e & 37.696 & 0.62 & 3145 \\
\hline 24 & gamma-Sitosterol & 41.390 & 1.24 & $\mathrm{NC}$ \\
\hline
\end{tabular}

* Retention time; ** Kováts index of sample; NC means not calculated due to the lack of normal alkane atoms

Ethanolic extract of thyme was the most active against the growth by $S$. aureus and $C$. albicans, and it possessed good antibacterial and antifungal activity. The chemical components identified in the ethanolic extract from leaves and branches of $Z$. multiflora are presented in Table 4 . The main constituents were carvacrol $(52.32 \%)$, linalool L (15.96\%), thymol (9.59\%), 1-methylpyrroline (3.53\%), and trans-caryophyllene $(3.43 \%)$. Thymol was the main constituent of the fresh plant $(73.21 \%)$, while carvacrol was the primary constituent in the dried plant (62.87\%) (Saleem et al. 2004). Carvacrol and thymol 
are well-known anti-fungal agents in the essential oil of Z. multiflora with significant amounts (Baser 2008; Shokri et al. 2011, 2012; Abbaszadeh et al. 2014). It was concluded that several factors, such as geographical variation, cultivar differences, stage of plant growth, preparation, and extraction process, may not affect only the quantitative properties of the essential oil composition but additionally influence its qualitative ones (Ali et al. 1999a, 1999b). The aromadendrene was found in a low content (0.40\%) (Dezaki et al. 2016). Phytol with minor and trace concentration was found (0.34\%) (Martínez-Pérez et al. 2007).

\section{Chemical composition of rosemary extract}

Ethanolic extract of rosemary at different concentrations did not exhibit acceptable antifungal and antibacterial effects against $C$. albicans and $S$. aureus, and it also possessed little to weak antimicrobial activity. The chemical components identified in the ethanolic extract from leaves and branches of $R$. officinalis are presented in Table 5.

The main constituents were $\beta$-amyrone $(18.00 \%)$, verbenone $(8.00 \%), 1,8$-cineole (7.26\%), camphor $(6.09 \%), 3,8,9$-trimethoxy-6H-dibenzo[b,d]pyran-6-one $(6.63 \%)$, bornyl acetate $(6.01 \%)$, trans-caryophyllene (4.86\%), and borneol L (3.24\%) (Pintore et al. 2001; Genena et al. 2008; Senanayake 2013; Karakaya et al. 2014; Jan et al. 2017).

The (23S)-ethylcholest-5-en-3.beta.-ol was found in a low content (0.53\%). Pinocamphone $(0.44 \%)$, also known as 3-pinanone, belongs to the class of organic compounds and as bicyclic monoterpenoids, was found with trace concentration $(0.34 \%)$ (Jan et al. 2017; Kulak 2019).

Table 5. Characterized Chemical Composition of Ethanolic Extract of $R$. officinalis

\begin{tabular}{|c|c|c|c|c|}
\hline No. & Compound & $\begin{array}{c}\mathbf{R T}^{*} \\
(\mathbf{m i n})\end{array}$ & $\begin{array}{c}\text { Relative Area } \\
\text { Percent (\%) }\end{array}$ & $\mathbf{K I}^{* *}$ \\
\hline 1 & B-Myrcene & 6.274 & 0.85 & $\mathrm{NC}$ \\
\hline 2 & $1,8-$-Cineole & 7.119 & 7.26 & 1037 \\
\hline 3 & Linalool L & 8.577 & 0.88 & 1103 \\
\hline 4 & Camphor & 9.537 & 6.09 & 1152 \\
\hline 5 & Pinocamphone & 9.875 & 0.44 & 1167 \\
\hline 6 & Borneol L & 10.009 & 3.24 & 1174 \\
\hline 7 & A-Terpineol & 10.534 & 0.66 & 1197 \\
\hline 8 & Verbenone & 10.902 & 8.00 & 1216 \\
\hline 9 & Bornyl acetate & 12.401 & 6.01 & 1291 \\
\hline 10 & Trans-caryophyllene & 15.006 & 4.86 & 1430 \\
\hline 11 & A-Humulene & 15.624 & 0.76 & 1464 \\
\hline
\end{tabular}

* Retention time; ** Kováts index of sample; NC means not calculated due to the lack of normal alkane atoms 
Table 5. Characterized Chemical Composition of Ethanolic Extract of $R$. officinalis (Continued)

\begin{tabular}{|c|c|c|c|c|}
\hline No. & Compound & $\begin{array}{l}\mathbf{R T}^{*} \\
(\mathbf{m i n})\end{array}$ & $\begin{array}{c}\text { Relative Area } \\
\text { Percent (\%) }\end{array}$ & $\mathbf{K I}^{* *}$ \\
\hline 12 & $\beta$-elemene & 19.126 & 0.92 & 1672 \\
\hline 13 & Neophytadiene & 21.725 & 0.61 & 1842 \\
\hline 14 & n-Hexadecanoic acid & 23.567 & 2.61 & 1971 \\
\hline 15 & Methyl heptadecyl ketone & 24.066 & 1.23 & 2007 \\
\hline 16 & Phytol & 25.539 & 1.97 & 2117 \\
\hline 17 & Linoleic acid & 25.959 & 2.76 & 2151 \\
\hline 18 & 9,12-Octadecadienoic acid (Z,Z)- & 26.224 & 1.38 & 2171 \\
\hline 19 & $\begin{array}{c}\text { (+)-5-Methyl-6(S)-(3-methyl-2- } \\
\text { butenyl)tetrahydroimidazo[4,5,1- } \\
\mathrm{jk}][1,4] \text { benzodiazepin-2(1H)-one }\end{array}$ & 27.365 & 1.39 & 2264 \\
\hline 20 & $\begin{array}{c}2,2^{\prime}\left(1 \mathrm{H}, 1^{\prime} \mathrm{H}\right) \text {-Spirobi-s-indacene, ethanone } \\
\text { deriv. }\end{array}$ & 28.263 & 0.68 & 2338 \\
\hline 21 & $\begin{array}{l}\text { Ferruginol } \\
\end{array}$ & 28.362 & 1.00 & 2347 \\
\hline 22 & $\begin{array}{c}\text { 1,2-Dicyano-1-(1,2-dimethyl-3-indolyl)-2- } \\
\text { (1,2,4,5-tetramethyl-3-pyrrolyl)ethane }\end{array}$ & 28.528 & 0.74 & 2361 \\
\hline 23 & Pyrido[2,3-b]indole & 28.896 & 2.93 & 2392 \\
\hline 24 & Benzo[c]coumarine, 3,4,8-trimethoxy- & 29.161 & 1.86 & 2415 \\
\hline 25 & 4-Hydroxy-3,3',4-trimethoxystilbene & 29.306 & 2.53 & 2428 \\
\hline 26 & 3,8,9-Trimethoxy-6H-dibenzo[b,d]pyran-6-one & 30.235 & 6.63 & 2510 \\
\hline 27 & Cyproheptadine & 30.515 & 0.64 & 2536 \\
\hline 28 & Squalene & 33.613 & 1.05 & 2833 \\
\hline 29 & D,a.-Tocopherol & 37.701 & 1.16 & 3145 \\
\hline 30 & (23S)-Ethylcholest-5-en-3- $\beta$-ol & 41.422 & 0.53 & $\mathrm{NC}$ \\
\hline 31 & $\beta$-Amyrone & 41.608 & 18.00 & $\mathrm{NC}$ \\
\hline 32 & Handianol & 43.455 & 0.66 & NC \\
\hline
\end{tabular}

* Retention time; ** Kováts index of sample; NC means not calculated due to the lack of normal alkane atoms

Based on the previous reports, the biological activities, including antioxidant and antimicrobial activities of rosemary, are related to the non-nutrient secondary metabolites of the plant such as the phenolic diterpenes, carnosol, carnosic acid, methyl carnosate, rosmanol, epirosmanol, and phenolic acids such as ferulic, rosmarinic, and chlorogenic and caffeic acids (Chen et al. 1996; Cuvelier et al. 1996; Frankel et al. 1996b; Richheimer et al. 1996; Huang et al. 1997; Campo et al. 2000; Wellwood and Cole 2004; Peñuelas and Munné-Bosch 2005; Moreno et al. 2006).

The thyme oil antifungal effects against Coniophora puteana and Aspergillus niger was also confirmed by Jones et al. (2011). Bahmani and Schmidt (2018) after impregnation of Fagus orientalis and Pinus taeda wood with lavender, lemongrass, and thyme oils confirmed that these oils could ensure efficient protection against A. niger, Penicillium commune, C. puteana, Trametes versicolor, and Chaetomium globosum.

Voda et al. (2003) using the agar dilution method showed that the anise, basil, cumin, oregano, and thyme oils have had high antifungal effects against brown-rot fungus C. puteana and white-rot fungus $T$. versicolor. They also concluded that thymol, carvacrol, 
trans-anethole, methyl chavicol, and cuminaldehyde were the most effective compounds in inhibiting the growth of both fungi.

Additionally, Reinprecht et al. (2019) in their studies on five different essential oils (basil, cinnamon, clove, oregano, and thyme), found that the highest antifungal activity against brown-rot fungus Serpula lacrymans and the white-rot fungus $T$. versicolor was shown for basil oil (containing mainly linalool), and the lowest was noted for clove oil (containing mainly eugenol).

The antifungal effectiveness and stability of beech wood treated with $10 \%$ solutions of ten different essential oils (birch, clove, lavender, oregano, sweet flag, savory, sage, tea tree, thyme, and a mixture of eucalypt, lavender, lemon, sage, and thyme oils) against brown-rot fungus $C$. puteana and white-rot fungus $T$. versicolor were examined by Pánek et al. (2014). They showed that after a complex accelerated ageing procedure the most effective against $C$. puteana were clove, oregano, sweet flag, and thyme oils that contain phenol compounds such as carvacol, eugenol, thymol, and cis-isoasarol trimethylether.

According to the previous studies and findings of researchers, the authors found that the thyme ethanolic (obtained by $96 \%$ ethanol) extract containing the mentioned compounds with a concentration of $40 \%$ and probably the rosemary ethanolic extract with low concentration can have potential effects on wood protection as a benign environmentfriendly preservative.

\section{CONCLUSIONS}

In this study, the inhibitory effect of ethanolic extracts of thyme and rosemary on fungus and bacteria was tested.

1. According to the fungal inhibition results, Zataria multiflora extract had a higher antibacterial and antifungal effects than rosemary extract.

2. Z. multiflora at $30 \%$ and $40 \%$ concentrations showed the highest effect on the growth of bacteria $S$. aureus and at $40 \%$ concentration showed the highest effect on the growth of fungus $C$. albicans.

3. According to the classification of IZD, the thyme extract is placed in two classes of moderate to strong, but the rosemary extract is placed in two classes of little or no response to weak.

4. The thyme ethanolic (obtained by $96 \%$ ethanol) extract with a concentration of $40 \%$ can have potential effect on wood protection as a benign environment-friendly preservative.

\section{ACKNOWLEDGMENTS}

The authors are grateful for the support of the Department of Wood Science and Paper Technology and the Department of Horticulture, Karaj Branch, Islamic Azad University. 


\section{REFERENCES CITED}

Abbaszadeh, S., Sharifzadeh, A., Shokri, H., Khosravi, A. R., and Abbaszadeh, A. (2014). "Antifungal efficacy of thymol, carvacrol, eugenol and menthol as alternative agents to control the growth of food-relevant fungi," J. Mycol. Med. 24(2), e51-e56. DOI: 10.1016/j.mycmed.2014.01.063

Abdulaziz, S. M., Shaswary, I. A., and Muhammad, A. A. (2015). "In vitro antifungal activity of essential oils from local plants against fluconazole-resistant oral Candida albicans isolates," Zanco J. Med. Sci. 19(2), 965-971. DOI: 10.15218/zjms.2015.0018

Adams, R. P. (1995). Identification of Essential Oil Components by Gas Chromatography/Mass Spectrometry, Allured Publishing Co., Carol Stream, IL, USA.

Adams, R. P. (2001). Identification of Essential Oil Components by Gas Chromatography/Quadrupole Mass Spectroscopy, $3^{\text {rd }}$ Edition, Allured Publishing Corp., Carol Stream, IL, USA.

Ali, M. S., Saleem, M., Akhtar, F., Jahangir, M., Parvez, M., and Ahmad, V. U. (1999b). "Three p-cymene derivatives from Zataria multiflora," Phytochem. 52(4), 685-688. DOI: 10.1016/S0031-9422(99)00259-9

Ali, M. S., Saleem, M., Ali, Z., and Ahmad, V. U. (2000). "Chemistry of Zataria multiflora (Lamiaceae)," Phytochem. 55(8), 933-936. DOI: 10.1016/s00319422(00)00249-1

Ali, M. S., Saleem, M., and Ahmad, V. U. (1999a). "Zatatriol: A new aromatic constituent from Zataria multiflora," Z. Naturforsch. C. J. Biosci. 54(6), 807-810. DOI: 10.1515/znb-1999-0616

Atti-Santos, A. C., Rossato, M., Pauletti, G. F., Rato, L. D., Rech, J. C., Pansera, M. R., Agostini, F., Serafini, L. A., and Moyne, P. (2005). "Physico-chemical evaluation of Rosmarinus officinalis L. essential oils," Braz. Arc. Biol. Technol. 48(6), 1035-1039. DOI: $10.1590 / \mathrm{S} 1516-89132005000800020$

Azizkhani, M., and Tooryan, F. (2015). "Antioxidant and antimicrobial activities of rosemary extract, mint extract and a mixture of tocopherols in beef sausage during storage at 4C," J. Food Saf. 35(1), 128-136. DOI: 10.1111/jfs.12166

Babaie, M., Yassa, N., Mohammadirad, A., Khorasani, R., and Abdollahi, M. (2007). "On the anti oxidative stress potential of Zataria multiflora Boiss (Avishan-e Shirazi) in rats," Int. J. Pharmacol. 3(6), 510-514. DOI: 10.3923/ijp.2007.510.514

Bachheti, R. K., Joshi, A., and Singh, A. (2011). "Oil content variation and antimicrobial activity of eucalyptus leaves oils of three different species of Dehradun, Uttarakhand, India," Int. J. ChemTech. Res. 3(2), 625-628.

Bahmani, M., and Schmidt, O. (2018). "Plant essential oils for environment-friendly protection of wood objects against fungi," Maderas-Cienc. Tecnol. 20(3), 325-332. DOI: $10.4067 /$ S0718-221X2018005003301

Balouiri, M., Sadiki, M., and Koraichi Ibnsouda, S. (2016). "Methods for in vitro evaluating antimicrobial activity: A review," J. Pharm. Anal. 6(2), 71-79. DOI: 10.1016/j.jpha.2015.11.005

Baser, K. H. C. (2008). "Biological and pharmacological activities of carvacrol and carvacrol bearing essential oils," Curr. Pharm. Des. 14(29), 3106-3120. DOI: $10.2174 / 138161208786404227$ 
Bidaki, M. Z., Arab, M., Khazaei, M., Afkar, E., and Zardast, M. (2015). “Anti-bacterial effect of Zataria multiflora Boiss. Essential oil on eight gastrointestinal pathogenic species," Horizon Med. Sci. 21(3), 155-161. DOI: 10.18869/acadpub.hms.21.3.155

Bineshian, F., Bakhshandeh, N., Taherian, K., and Nazari, H. (2018). "GC-MS analysis of anti-Candida and antioxidant activities of hydroalcoholic leaf extract of Chaerophyllum macropodum," Jundishapur J. Nat. Pharm. Prod. 13(4), Article ID e13207. DOI: 10.5812/jjnpp.13207

Campo, J. D., Amiot, M. J., and Nguyen-The, C. (2000). “Antimicrobial effect of rosemary extracts,” J. Food Prot. 63(10), 1659-1368. DOI: 10.4315/0362-028x63.10 .1359

Chen, S. S., Ostric-Matijasevic, B., Hsieh, O. A. L., and Huang, C. L. (1996). "Natural antioxidants from rosemary and sage," J. Food Sci. 42(4), 1102-1104. DOI: 10.1111/j.1365-2621.1977.tb12676.x

Cuvelier, M. E., Richard, H., and Berset, C. (1996). "Antioxidative activity and phenolic composition of pilot-plant and commercial extracts of sage and rosemary," J. Am. Oil. Chem. Soc. 73(5), 645-652. DOI: 10.1007/BF02518121

Dezaki, E., Mahmoudvand, H., Sharififar, F., Fallahi, S., Monzote, L., and Ezatkhah, F. (2016). "Chemical composition along with anti-leishmanial and cytotoxic activity of Zataria multiflora," Pharm. Biol. 54(5), 752-758. DOI: 10.3109/13880209.2015.1079223

Fazeli, M. R., Amin, G., Attari, M. M. A., Ashtiani, H., Jamalifar, H., and Samadi, N. (2007). "Antimicrobial activity of Iranian sumac and Avishan-e shirazi (Zataria multiflora) against some food-borne bacteria," Food Control 18(6), 646-649. DOI: 10.1016/j.foodcont.2006.03.002

Fazlara, A., Najafzadeh, H., and Lak, E. (2008). "The potential application of plant essential oils as natural preservatives against Escherichia coli O157:H7," Pak. J. Biol. Sci. 11(17), 2054-2061. DOI: 10.3923/pjbs.2008.2054.2061

Frankel, E. N., Huang, S., Prior, E., and Aeshbach, R. (1996a). "Evolution of antioxidant activity of rosemary extracts, carnosol and carnosolic acid in bulk vegetable oils and fish oil and their emulsion," J. Sci. Food Agric. 72(2), 201-208. DOI: 10.1002/(SICI)1097-0010(199610)72:2<201::AID-JSFA632>3.0.CO;2-Q

Frankel, E. N., Huang, S. W., Aeschbach, R., and Prior, E. (1996b). "Antioxidant activity of a rosemary extract and its constituents, carnosic acid, carnosol, and rosmarinic acid, in bulk oil and oil-in-water emulsion," J. Agric. Food Chem. 44(1), 131-135. DOI: $10.1021 /$ jf950374p

Gandomi, H., Misaghi, A., Akhondzadeh Basti, A., Bokaei, S., Khosravi, A., Abbasifar, A., and Javan, A. J. (2009). "Effect of Zataria multiflora Boiss. essential oil on growth and aflatoxin formation by Aspergillus flavus in culture media and cheese," Food Chem. Toxicol. 47(10), 2397-400. DOI: 10.1016/j.fct.2009.05.024

Genena, A. K., Hense, H., Smânia Junior, A., and De Souza, S. M. (2008). "Rosemary (Rosmarinus officinalis) - A study of the composition, antioxidant and antimicrobial activities of extracts obtained with supercritical carbon dioxide," Ciênc. Tecnol. Aliment. 28(2), 463-469. DOI: 10.1590/S0101-20612008000200030

Goudarzi, M., Sattari, M., Najar Piraieh, S., Goudarzi, G., and Bigdeli, M. (2006). "Antimicrobial effects of aqueous and alcoholic extracts of thyme on enterohmorrhagic Escherichia coli," Yafte 8(3), 63-69.

Hashemi, M., Ehsani, A., Jazani, N. H., Aliakbarlu, J., and Mahmoudi, R. (2013). "Chemical composition and in vitro antibacterial activity of essential oil and 
methanol extract of Echinophora platyloba D. C against some of food-borne pathogenic bacteria," Vet. Res. Forum 4(2), 123-127.

Huang, S. W., Frankel, E. N., Aeschbach, R., and German, J. B. (1997). "Partition of selected antioxidants in corn oil-water model systems," J. Agric. Food Chem. 45(6), 1991-1994. DOI: 10.1021/jf9701695

Jan, A. K., Khan, N. M., Rehman, N., Rauf, A., Farooq, U., Khan, A., and Khan, H. (2017). "Chemical composition and biological profile of essential oil of Rosmarinus officinalis L.," Sci. Technol. Develop. 36(1), 1-5. DOI: 10.3923/std.2017.1.5

Jones, D., Howard, N., and Suttie, E. (2011). "The potential of propolis and other naturally occurring products for preventing biological decay," in: Proceedings of the $42^{\text {nd }}$ Annual Meeting of the International Research Group on Wood Protection, Queenstown, New Zealand.

Joulain, D., and König, W. A. (1988). The Atlas of Spectral Data of Sesquiterpene Hydrocarbons, E. B. Verlag, Harburg, Germany.

Kadariya, J., Smith, T. C., and Thapaliya, D. (2014). "Staphylococcus aureus and staphylococcal food-borne disease: An ongoing challenge in public health," Biomed. Res. Int. 2014, Article ID 827965. DOI: 10.1155/2014/827965

Karakaya, S., El, S. N., Karagozlu, N., Sahin, S., Sumnu, G., and Bayramoglu, B. (2014). "Microwave-assisted hydrodistillation of essential oil from rosemary," J. Food Sci. Technol. 51(6), 1056-1065. DOI: 10.1007/s13197-011-0610-y

Kováts, E. (1958). "Characterization of organic compounds by gas chromatography. Part 1. Retention indices of aliphatic halides, alcohols, aldehydes and ketones," Helv. Chim. Acta. 41(7), 1915-1932. DOI: 10.1002/hlca.19580410703

Kulak, M. (2019). "A time-course study on essential oil of rosemary (Rosmarinus officinalis) under drought stress," Adlyaman Univ. J. Sci. 9(1), 165-189.

Lowy, F. D. (1998). "Medical progress: Staphylococcus aureus infection," The New England J. Med. 339(8), 520-532. DOI: 10.1056/NEJM199808203390806

Martínez-Pérez, Y., Quijano-Celís, C. E., and Pino, J. A. (2007). "Volatile constituents of Cuban thyme oil (Thymus vulgaris L.)," J. Essent. Oil Bear. Plants 10(3), 179-183. DOI: 10.1080/0972060X.2007.10643539

Matsuzaki, Y., Tsujisawa, T., Nishihara, T., Nakamura, M., and Kakinoki, Y. (2013). "Antifungal activity of chemotype essential oils from rosemary against Candida albicans," Open J. Stomatol. 3(2), 176-182. DOI: 10.4236/ojst.2013.32031

Mirheydar, H. (2001). Herbal Information: Usage of Plants in Prevention and Treatment of Disease, Islamic Culture Press Center, Tehran, Iran.

Misaghi, A., and Basti, A. A. (2007). "Effects of Zataria multiflora Boiss. essential oil and nisin on Bacillus cereus ATCC 11778," Food Control 18(9), 1043-1049. DOI: 10.1016/j.foodcont.2006.06.010

Moreno, S., Scheyer, T., Romano, C. S., and Vojnov, A. A. (2006). “Antioxidant and antimicrobial activities of rosemary extracts linked to their polyphenol composition," Free Radic. Res. 40(2), 223-231. DOI: 10.1080/10715760500473834

Mutai, C., Bii, C., Vagias, C., Abatis, D., and Roussis, V. (2009). “Antimicrobial activity of Acacia mellifera extracts and lupine triterpenes," J. Ethnopharmacol. 123(1), 143148. DOI: 10.1016/j.jep.2009.02.007

Pánek, M., Reinprecht, L., and Hulla, M. (2014). "Ten essential oils for beech wood protection efficacy against wood-destroying fungi and moulds, and effect on wood discoloration," BioResources 9(3), 5588-5603. DOI: 10.15376/biores.9.3.5588-5603 
Peñuelas, J., and Munné-Bosch, S. (2005). "Isoprenoids: An evolutionary pool for photoprotection," Trends Plant Sci. 10(4), 166-169. DOI:

10.1016/j.tplants.2005.02.005

Pintore, G., Usai, M., Bradesi, P., Juliano, C., Boatto, G., Tomi, F., Chessa, M., Cerri, R., and Casanova, J. (2001). "Chemical composition and antimicrobial activity of Rosmarinus officinalis L. oils from Sardinia and Corsica," Flavour Fragr. J. 17(1), 15-19. DOI: 10.1002/ffj.1022

Raeisi, M., Bidkorpeh, F. G., Hashemi, M., Tepe, B., Moghaddam, Z., Mohammadi, M. A., and Noori, S. M. A. (2019). "Chemical composition and antibacterial and antioxidant properties of essential oils of Zataria multiflora, Artemisia deracunculus and Mentha piperita," Med. Lab. J. 13(2), 1-7. DOI: 10.29252/mlj.13.2.1

Ramezani, M., Hosseinzadeh, H., and Samizadeh, S. (2004). "Antinociceptive effects of Zataria multiflora Boiss fractions in mice," J. Ethnopharmacol. 91(1), 167-170. DOI: 10.1016/j.jep.2003.12.016

Rathi, B. S., Bodhankar, S. L., and Baheti, A. M. (2006). "Evaluation of aqueous leaves extract of Moringa oleifera Linn for wound healing in albino rats," Indian J. Exp. Biol. 44(11), 898-901.

Reinprecht, L., Pop, D.-M., Vidholdová, Z., and Timar, M. C. (2019). “Anti-decay potential of five essential oils against the wood-decaying fungi Serpula lacrymans and Trametes versicolor," Acta Fac. Xylol. Zvolen Res Publica Slovaca 61(2), 63-72. DOI: 10.17423/afx.2019.61.2.06

Richheimer, S. L., Bernart, M. W., King, G. A., Kent, M. C., and Bailey, D. T. (1996). "Antioxidant activity of lipid-soluble phenolic diterpenes from rosemary," J. Am. Oil Chem. Soc. 73(4), 507-514. DOI: 10.1007/BF02523927

Sadeghi-Nejad, B., Fariba, S., Somayeh, G., Mastaneh, A., and Majid, Z. (2010). "Antifungal activity of Satureja khuzestanica (Jamzad) leaves extracts," Jundishapur J. Microbiol. 3(1), 36-40.

Saei-Dehkordi, S. S., Tajik, H., Moradi, M., and Khalighi-Sigaroodi, F. (2010). "Chemical composition of essential oils in Zataria multiflora Boiss. from different parts of Iran and their radical scavenging and antimicrobial activity," Food Chem. Toxicol. 48(6), 1562-1567. DOI: 10.1016/j.fct.2010.03.025

Sajed, H., Sahebkar, A., and Iranshahi, M. (2013). "Zataria multiflora Boiss. (Shirazi thyme)-An ancient condiment with modern pharmaceutical uses," $J$. Ethnopharmacol. 143(3), 686-698. DOI: 10.1016/j.jep.2012.12.018

Saleem, M., Nazli, R., Afza, N., Sami, A., and Ali, M. S. (2004). "Biological significance of essential oil of Zataria multiflora Boiss," Nat. Prod. Res. 18(6), 493-497. DOI: 10.1080/14786410310001608064

Senanayake, S. P. J. N. (2013). "Rosemary and green tea extracts as natural antioxidants: Chemistry, technology, and applications," in: Lipid oxidation: Challenges in food systems, A. Logan, U. Nienabar, and X. Pan (eds.), AOCS Press, Urbana, IL, USA, pp. 439-456.

Shafiee, A., and Javidnia, K. (1997). "Composition of essential oil of Zataria multiflora," Planta Medica 63(4), 371-372. DOI: 10.1055/s-2006-957707

Shokri, H., Asadi, F., Bahonar, A., and Khosravi, A. R. (2006). "The role of Zataria multiflora essence (Iranian herb) on innate immunity of animal model," Iranian J. Immunol. 3(4), 164-168. 
Shokri, H., Khosravi, A. R., Mansouri, M., and Ziglari, T. (2011). "Effects of Zataria multiflora and Geranium, Pelargonium essential oils on growth-inhibiting of some toxigenic fungi," Iran. J. Vet. Res. 12(3), 247-251. DOI: 10.22099/ijvr.2011.73

Shokri, H., Sharifzadeh, A., and Ashrafi Tamai, I. (2012). "Anti-Candida zeylanoides activity of some Iranian plants used in traditional medicine," J. Mycol. Med. 22(3), 211-216. DOI: 10.1016/j.mycmed.2012.04.006

Swari, D. A. M. A., Santika, I. W. M., and Aman, I. G. M. (2020). “Antifungal Activities of ethanol extract of rosemary leaf (Rosemarinus officinalis L.) against Candida albicans," J. Pharm. Sci. App. 2(1), 28-35. DOI: 10.24843/JPSA.2020.v02.i01.p05

Tavassoli, S. K., Mousavi, S. M., Emam-Djomeh, Z., and Razavi, S. H. (2011). "Chemical composition and evaluation of antimicrobial properties of Rosmarinus officinalis L. essential oil," Afr. J. Biotechnol. 10(63), 13895-13899. DOI: 10.5897/AJB11.788

Tiwari, B. K., Valdramidis, V. P., O’Donnell, C. P., Muthukumarappan, K., Bourke, P., and Cullen, P. J. (2009). "Application of natural antimicrobials for food preservation," J. Agric. Food Chem. 57(14), 5987-6000. DOI: 10.1021/jf900668n

Voda, K., Boh, B., Vrta cnik, M., and Pohleven, F. (2003). "Effect of the antifungal activity of oxygenated aromatic essential oil compounds on the white-rot Trametes versicolor and the brown-rot Coniophora puteana," Int. Biodeter. Biodegr. 51(1), 5159. DOI: 10.1016/S0964-8305(02)00075-6

Wellwood, C. R. L., and Cole, R. A. (2004). "Relevance of carnosic acid concentrations to the selection of rosemary, Rosmarinus officinalis (L.), accessions for optimization of antioxidant yield," J. Agric. Food Chem. 52(20), 6101-6107. DOI: $10.1021 / \mathrm{jf035335p}$

Yanishlieva, N. V., Marinova, E. M., Gordon, M. H., and Raneva, V. G. (1999). "Antioxidant activity and mechanism of action of thymol and carvacrol in two lipid systems," Food Chem. 64(1), 59-66. DOI: 10.1016/S0308-8146(98)00086-7

Article submitted: September 15, 2020; Peer review completed: October 25, 2020;

Revised version received and accepted: October 27, 2020; Published: October 30, 2020. DOI: 10.15376/biores.15.4.9656-9671 